\title{
FULL PAPER \\ Differential cytokine genotype frequencies among Canadian Aboriginal and Caucasian populations
}

\author{
L Larcombe $^{1}$, JD Rempel ${ }^{2}$ I Dembinski ${ }^{2}, \mathrm{~K}_{\text {Tinckam }}{ }^{2}, \mathrm{C} \mathrm{Rigatto}^{2}$ and P Nickerson ${ }^{2}$ \\ ${ }^{1}$ Department of Anthropology, University of Manitoba, 435 Fletcher Argue Bldg Winnipeg, Manitoba, Canada; ${ }^{2}$ Faculty of Medicine, \\ University of Manitoba, 730 William Avenue Winnipeg, Manitoba, Canada
}

\begin{abstract}
Genetic diversity related to the human immune response is a key factor in individual and population survival throughout human history. Population diversity in disease susceptibility and resistance have been identified and linked to differences in cytokine $m R N A$ and protein expression levels. Polymorphisms in the regulatory regions of cytokine genes can influence gene transcription levels and they have been associated with susceptibility to, and/or severity of, autoimmune disorders such as rheumatoid arthritis, meningococcus and sepsis. It is reported here that in two study populations, Canadian Aboriginal individuals have a higher frequency of cytokine single-nucleotide polymorphisms favouring a low production of TNF $\alpha$, IFNy and IL-10 and high production of IL-6 as compared to a Caucasian population. We postulate that the evolution of this unique cytokine genotype profile may be linked to the Aboriginal adaptation to selection pressures related to an environment in which helminthic, parasitic and fungal infections predominated.
\end{abstract}

Genes and Immunity (2005) 6, 140-144. doi:10.1038/sj.gene.6364157

Published online 23 December 2004

Keywords: cytokine polymorphisms; population; diversity; North American Aboriginal; Caucasian; Filipino; selective pressures

\section{Introduction}

Infectious pathogens such as Mycobacterium tuberculosis and Respiratory Syncytial Virus (RSV) continue to have a devastating effect on certain North American subpopulations. ${ }^{1-6}$ For example, in Canada, $43 \%$ of all new active and relapsed cases of tuberculosis occur among Aboriginals, 37\% occur among foreign-born individuals and $20 \%$ among Canadian born nonAboriginals. ${ }^{2}$ While most studies focus on socioeconomic differences, ${ }^{7-9}$ little attention has been paid to the genetic differences that may exist between human populations that could regulate the quality of the immune response to a given pathogen. In contrast, studies of inbred mice have clearly demonstrated that the genetic background plays a key role in determining the quality of the cytokine response (eg $\mathrm{T}_{\mathrm{h}} 1$ vs $\mathrm{T}_{\mathrm{h}} 2$ ), which in turn affects the host's ability to eradicate an infectious agent (ie Leishmania major, Toxoplasma gondii, M. tuberculosis). ${ }^{10-14}$

With the completion of the human genome project, it has become apparent that single-nucleotide polymorphisms (SNPs) are common and depending on location may affect gene transcription levels. ${ }^{15}$ In the context of the host's immune response to an infectious agent, the identification of differences in cytokine SNP profiles may have important implications for the host's resistance or

Correspondence: $\mathrm{Dr}$ L Larcombe, 43 St Edmund's Bay, Winnipeg, Manitoba, Canada R3T 3M5. E-mail: larcombe@mts.net

Received 1 July 2004; revised 22 October 2004; accepted 2 November 2004; published online 23 December 2004 susceptibility to that particular pathogen. The current study describes the frequency of SNPs, which are known to correlate with differential gene expression for the IL-6, IL-10, TNF $\alpha$, IFN $\gamma$ and TGF- $\beta_{1}$ genes, in Caucasian, Canadian Aboriginal and Filipino cohorts and postulates why such distinct cytokine SNP profiles may have evolved at a population level. ${ }^{16-23}$

\section{Results}

In two independent studies, it was found that ethnic populations have statistically different cytokine SNP profiles. It was initially observed that cytokine genotypes of North American Aboriginals and Filipinos with ESRD had significantly different cytokine genotypes as compared to a Caucasian with end-stage renal disease (ESRD) cohort (Table 1). A second study, which involved normal control populations of Caucasian and Aboriginal individuals, validated the initial observations (Table 2 ).

As compared to the Aboriginal and Filipino cohorts, Caucasians maintain a higher frequency of the TNF $\alpha$ $(-308)$ and IFN $\gamma$ allele SNPs whose phenotypic expression are associated with enhanced production of these cytokines. ${ }^{16-19,24,25}$ In contrast to the Caucasian cohort, individuals of Aboriginal and Filipino descent had a high frequency of the IL-6 (-174) allele, associated with a higher production of this cytokine. ${ }^{22,23}$ The Aboriginal individuals maintained a statistically higher frequency of the ' $G$ ' allele at the TNF $\alpha(-308)$ loci and would therefore tend to be low producers of this cytokine as compared to 
Table 1 Cytokine phenotype frequencies by percent for patients with ESRD

\begin{tabular}{llll}
\hline Cytokine & $\begin{array}{l}\text { Caucasian } \\
\operatorname{ESRD}(H, I, L)\end{array}$ & $\begin{array}{l}\text { Aboriginal } \\
\operatorname{ESRD}(H, I, L)\end{array}$ & $\begin{array}{l}\text { Filipino } \\
\operatorname{ESRD}(H, I, L)\end{array}$ \\
\hline TNF $\alpha$ & $3,29,68$ & $1,10,88^{*}$ & $0,4,96^{*}$ \\
IFN $\gamma$ & $19,46,35$ & $6,24,69^{*}$ & $8,31,62^{*}$ \\
IL-10 (-1082) & $20,47,33$ & $9,37,53^{*}$ & $0,4,96^{*}$ \\
IL-10 (-592) & $58,32,10$ & $37,42,20^{*}$ & $11,35,54^{*}$ \\
IL-10 (-819) & $58,32,10$ & $37,42,20^{*}$ & $11,35,54^{*}$ \\
IL-6 & $38,45,17$ & $82,17,1^{*}$ & $96,0,4^{*}$ \\
TGF $\beta$ codon 25 & $87,12,1$ & $97,3,0^{*}$ & $96,4,0$ \\
TGF $\beta$ codon 10 & $35,50,15$ & $33,49,18$ & $31,38,31$ \\
\hline
\end{tabular}

${ }^{*} P<0.005$ when compared to Caucasian population.

Table 2 Cytokine phenotype frequencies by percent for normal controls

\begin{tabular}{lll}
\hline Cytokine & $\begin{array}{l}\text { Caucasian normal } \\
\text { controls }(H, I, L)\end{array}$ & $\begin{array}{l}\text { Aboriginal normal } \\
\text { control }(H, I, L)\end{array}$ \\
\hline TNF $\alpha$ & $3,29,68$ & $0,7,93^{*}$ \\
IFN $\gamma$ & $20,53,27$ & $4,20,76^{*}$ \\
IL-10 (-1082) & $22,56,22$ & $6,32,62^{*}$ \\
IL-10 (-592) & $61,38,1$ & $34,50,16^{*}$ \\
IL-10 (-819) & $61,38,1$ & $34,50,16^{*}$ \\
IL-6 & $35,48,17$ & $86,14,0^{*}$ \\
TGF Codon 25 & $85,14,1$ & $94,6,0^{*}$ \\
TGF $\beta$ Codon 10 & $42,48,11$ & $25,61,14$ \\
\hline
\end{tabular}

${ }^{*} P<0.005$ when compared to Caucasian population.

the Caucasian cohort. Similarly, the Aboriginals maintained a statistically higher frequency of the ' $A$ ' allele at the IFN $\gamma$ loci, which would be associated with low production of IFN $\gamma$. The allele frequencies of IL-10 $(-819)$ and IL-10 (-592) were similarly distributed in a given population, which would suggest that these loci are in linkage disequilibrium. However, the Aboriginals had IL-10 loci phenotypes skewed towards a lower production level of IL-10 as compared to the Caucasian cohort. In contrast, the Aboriginal group, as compared to the Caucasian cohort, had alleles associated with a higher expression level for IL-6 (' $G$ ' allele at -174) and TGF $\beta_{1}$ ('G' allele codon 25). There was no statistical difference between allele frequencies of the Aboriginal and Caucasian groups for TGF $\beta_{1}$ (codon 10).

The Filipino patients exhibited the same differences as seen in the Aboriginal patients in cytokine genotype frequencies relative to the Caucasian cohort (Table 1). Interestingly, the only difference observed between the Aboriginal and Filipino patients was in relation to the IL10 promoter polymorphisms in which the Filipino group were skewed to be even lower IL-10 producers than the Aboriginal population.

\section{Discussion}

The novel observation of this study relates to the fact that cytokine SNP profiles were distinct between the ethnic populations examined. In particular, the genotype profile observed in this study suggests that Caucasians might favour a $T_{h} 1$ immune response, while the SNP frequencies in the Aboriginal and Filipino cytokine promoter regions would tend to favour a $\mathrm{T}_{\mathrm{h}} 2$ immune response. In order to account for these genetic differences, one should consider the historical context in which these populations evolved in relationship to their microbial environments.

The Old World Caucasian populations, during the past 11000 -year period, traded a hunting and gathering lifestyle, to one that included the domestication of plants and animals, sedentism and subsequently urbanization. These changes in subsistence and settlement patterns resulted in profound changes in the microbial environment in the Old World. ${ }^{26}$ With the advent of agriculture and urbanization, the so-called 'crowd infections' became prevalent and epidemics of smallpox, measles, plague and tuberculosis occurred throughout Europe. ${ }^{27,28}$ The high mortality rates associated with these pathogens likely exerted intensive selective pressures on the population. ${ }^{27}$ For example, given the high prevalence of tuberculosis infection leading to premature death in Europe (ca. 18th century), survival would have in part favoured those individuals who could effectively mount a delayed-type sensitivity (DTH) immune response. This type of response is characterized at a cytokine level by IFN $\gamma$ and TNF $\alpha$ expression. ${ }^{29}$ Indeed, when anti-TNF $\alpha$ was used to treat patients with inflammatory bowel disease, it was associated with the occurrence of, or the reactivation of, tuberculosis confirming the important role of $\mathrm{TNF} \alpha$ as an immune modulator or neutralizer for tuberculosis. ${ }^{30,31}$ To date, eight DNA variants have been identified in the TNF $\alpha$ promoter $(-1031 \mathrm{~T} / \mathrm{C},-863 \mathrm{C} / \mathrm{A}$, $-857 \mathrm{C} / \mathrm{T},-575 \mathrm{G} / \mathrm{A},-376 \mathrm{G} / \mathrm{A},-308 \mathrm{G} / \mathrm{A},-244 \mathrm{G} / \mathrm{A}$ and $-238 \mathrm{G} / \mathrm{A}$ ) and some of these polymorphisms have been linked to ethnicity and disease susceptibility and outcome. ${ }^{32-35}$ Certain SNPs in the TNF $\alpha$ promoter region have been implicated in the pathogenesis of infectious diseases such as malaria. For example, cerebral malaria has been associated with the TNF $\alpha$ (-308) 'A' allele, while severe malarial anemia was associated with the $\mathrm{TNF} \alpha(-238)$ 'A' allele. ${ }^{35,36}$ Studies have shown a higher $\mathrm{TNF} \alpha$ production phenotype in carriers with the ' $A$ ' allele suggesting that polymorphisms in the $T N F \alpha$ promoter region may have a direct affect on the outcome of malaria and other infectious diseases. ${ }^{16-18}$

Similarly, IFN $\gamma$ has an important role in a host's resistance to $M$. tuberculosis although IFN $\gamma$ production cannot adequately control the infection without the presence of other critical cytokines. ${ }^{37}$ While to date there is no evidence from population studies that common variants in the IFN $\gamma$ receptor genes affect susceptibility to tuberculosis, there are cases of inactivating mutations in the IFN $\gamma$ receptor, which was associated with susceptibility to usually nonpathogenic mycobacteria. ${ }^{29,38}$ In terms of other cytokines, evidence from animal models recently found that IL-6 expression by macrophages can prevent the effective containment of $M$. tuberculosis infection. ${ }^{14}$ Coming back then to the Caucasian population in this study, it is interesting to note that they maintain a relatively higher frequency of cytokine SNPs that would favour a delayed-type hypersensitivity response (ie IFN $\gamma, \mathrm{TNF} \alpha$ ) and a lower IL-6 expression level compared to the other cohorts. Given the aforementioned high prevalence of tuberculosis in Europe 
since ca. 1700 to the early 1900s when effective antimicrobial therapy was developed, then this might account for the cytokine SNP profile observed today in the Caucasian population.

In contrast, Aboriginal North American populations experienced a unique set of evolutionary pressures because of their migration across the Bering Land Bridge (ca. 15-20000 years ago) and their isolation from Old World populations until after ca. 1400 AD. ${ }^{39-44}$ The Aboriginals maintained an ancient mobile hunting and gathering lifestyle, which had existed in the Old World and that was conducive to the maintenance of diffuse settlements with low population densities. ${ }^{8,40,45-48}$ The analysis of pathologies from human skeletal remains of ancient Aboriginal individuals indicate that parasitic, fungal infections and malnutrition were present among the early populations. ${ }^{49-52}$ The consumption of raw or undercooked meat, living conditions that were confined during the winter months, and the pattern of collecting wild plants brought these people into close contact with fungi and parasites, and left them vulnerable to seasonal nutritional deficiency. This microbial environment would tend to favour positive selection for a $\mathrm{T}_{\mathrm{h}} 2$-type adaptive immune response in order to survive. Indeed, studies of South American Aboriginal families with Shistosoma mansoni infection have confirmed the protective role of $\mathrm{T}_{\mathrm{h}}$ 2-type cytokines IL-4, IL-6 and IL-13 in protection against parasitic infection. ${ }^{53}$ The overexpression of $T_{h} 2-$ type cytokines (IL-6 and IL-10) induces hyperactivity of B cells, which is characteristic of systemic lupus erythematosus, ${ }^{54}$ and the SNP at IL-6 (-174) was implicated in the age of onset of rheumatoid arthritis. ${ }^{55}$ Polymorphisms in the promoter regions of $\mathrm{TNF} \alpha, \mathrm{IFN} \gamma$, IL-10 and IL-6 are associated with differential expression levels of these cytokines and the maintenance of certain polymorphisms in a population may confer a selective advantage. ${ }^{16-23}$ In the context of the current study the fact that the Canadian Aboriginal cytokine SNP profile is skewed in favour of high IL-6 and relatively low TNF $\alpha$ and IFN $\gamma$ production would support the concept of a parasitic environment, and the low prevalence of $M$. tuberculosis in this population prior to European contact.

The Filipinos cytokine SNP frequencies are more similar to that of the North American Aboriginal population than either of these groups is to the Caucasians (Table 1). The common Asian heritage of the ancestral Aboriginal and Filipino populations, and their parallel migration away from the European continent before 12000 years ago, ${ }^{56,57}$ may account for these similarities.

Studies of infectious disease among Aboriginal populations have focused on socioeconomic factors contributing to disease resistance and susceptibility. ${ }^{1-3,58-60}$ In most of these studies, genetic differences between populations are acknowledged as contributing factors in disease susceptibility and resistance; however, the basis for this genetic disparity remains largely unexplored. Susceptibility to tuberculosis, for example, among the relatively isolated South American Aché is high. However, individuals with high nutritional and socioeconomic status within this group are equally at risk as those with low nutritional and socioeconomic status. ${ }^{61}$ It has been suggested that the high rates of antibody production and $\mathrm{T}_{\mathrm{h}} 2$-mediated activation by Aché individuals competes with the $T_{h} 1$-mediated defences required to effectively fight against infectious diseases such as tuberculosis. ${ }^{61}$ Similarly, North American Aboriginal populations in Manitoba have the highest incidence of tuberculosis relative to other local populations. ${ }^{1-3}$ While the unequal risk of disease between ethnic populations maybe partly explained by environmental and socioeconomic differences, cytokine SNPs may also play a role in this variability. Our current ongoing studies are testing this hypothesis.

In summary, ethnic affiliation is likely a factor in the observed differences of cytokine SNP frequencies. These differences between the Caucasian, Aboriginal and Filipino populations may in part reflect the fact that these populations have evolved in response to the selective pressures of their respective microbial environments.

\section{Materials and methods}

\section{Study populations}

ESRD patients were initially enrolled, with informed consent and approval of the University of Manitoba Institutional Review Board, into a study to explore the relationship between cytokine genotypes and inflammatory events (eg infection). However, it was noted that cytokine genotype profiles appeared to correlate with ethnicity and hence the following groups were identified to formally evaluate this relationship between cytokine SNPs and ethnicity further: North American Aboriginal with ESRD $(n=78)$, Caucasian with ESRD $(n=217)$ and Filipinos with ESRD $(n=26)$. To validate these initial observations and investigate host response to infectious disease, a separate study protocol was established and approved by the University of Manitoba Institutional Review Board. Herein, we report the results of the control groups consisting of Aboriginal $(n=130)$ and Caucasian individuals without ESRD $(n=116)$ that were consented. The age range of the cohort is approximately 18-60 years.

The North American Aboriginal cohort with ESRD was composed of self-proclaimed Status Indian individuals. Given the geographical location of the study centre in relation to the surrounding Aboriginal populations, the study group is likely Ojibwa or Cree. They are non-Caucasian and their respective heritages are considered to be native to North America. The Aboriginal control individuals are Oji-cree from a Reserve. In contrast, the Caucasian patients are of European descent. The Filipino population in Manitoba is largely derived from immigration from the Philippines that has occurred in the last 5-20 years.

\section{Cytokine genotyping}

Genomic DNA was extracted from buffy coat cells by absorption onto QIAamp silica-gel following QIAGEN protease digestion (Qiagen, Mississauga, Canada). After column elution, the purity and concentration of extracted DNA was determined by UV spectroscopy (BioRad, Mississauga, Canada). Single-nucleotide polymorphisms for IL-6, TNF $\alpha$, IFN $\gamma$, IL-10, TGF $\beta_{1}$ codon 25 and TGF $\beta_{1}$ codon 10 were determined using a commercial PCR-SSP kit (One Lambda, Canoga Park, USA). The specific gene polymorphisms probed for were as follows: $-174(\mathrm{G} / \mathrm{C})$ 
Table 3 Reporting for cytokine genotypes and phenotypes

\begin{tabular}{lll}
\hline Cytokine polymorphisms & Genotype & Phenotype producer \\
\hline TNF $\alpha(-308)$ & G/G & Low \\
& G/A & Intermediate \\
& A/A & High \\
TGF $\beta_{1}$ (codons 25) & G/G & High \\
& G/C & Intermediate \\
& C/C & Low \\
TGF $\beta_{1}$ (codons 10) & T/T & High \\
& T/C & Intermediate \\
& C/C & Low \\
IL-10 (-1082) & G/G & High \\
& G/A & Intermediate \\
& A/A & Low \\
IL-10 (-819) & C/C & High \\
& C/T & Intermediate \\
& T/T & Low \\
IL-10 (-592) & C/C & High \\
& C/A & Intermediate \\
& A/A & Low \\
IL-6 $(-174)$ & G/G & High \\
& G/C & Intermediate \\
& C/C & Low \\
& T/T & High \\
& A/A & Intermediate \\
& & Low \\
\hline & &
\end{tabular}

in the IL-6 promoter, $-1082(\mathrm{G} / \mathrm{A}),-819$ (T/C) and -592 $(\mathrm{A} / \mathrm{C})$ in the IL-10 promoter, $-308(\mathrm{G} / \mathrm{A})$ in the $\mathrm{TNF} \alpha$ promoter, codon $25(\mathrm{G} / \mathrm{C})$ and codon $10(\mathrm{~T} / \mathrm{C})$ of the $\mathrm{TGF}_{1}$ signal sequence and $+874(\mathrm{~T} / \mathrm{A})$ of intron 1 of IFN $\gamma$.

Each PCR reaction contained preoptimized sequencespecific primers, $100 \mathrm{ng}$ of genomic DNA, and 0.25 U Taq polymerase (PE Biosystems, Mississauga, Canada). Following the initial denaturation steps, samples were subjected to an initial nine rounds of PCR consisting of $96^{\circ} \mathrm{C}$ for $10 \mathrm{~s}, 63^{\circ} \mathrm{C}$ for $60 \mathrm{~s}$ followed by 20 rounds of PCR consisting of $96^{\circ} \mathrm{C}$ for $10 \mathrm{~s}, 56^{\circ} \mathrm{C}$ for $30 \mathrm{~s}$ and $72^{\circ} \mathrm{C}$ for $30 \mathrm{~s}$. To visualize the PCR products, $10 \mu \mathrm{l}$ of the amplified reaction was run in a $2.5 \%$ agarose gel containing $0.5 \%$ ethidium bromide at $150 \mathrm{~V}$ for $5 \mathrm{~min}$. DNA bands were then visualized with UV light on a transilluminator and photographed for subsequent analysis. Individuals (or samples) were classified into the predicted high, intermediate or low producer phenotypes according to their genotypes (Table 3 ).

\section{Statistical analyses}

Statistical analysis was performed using SAS software (SAS Institute, Cary, NC, USA). Values are reported as percentages. The Fisher Exact test was used for comparison of the categorical variables. $P<0.01$ are reported as significant. This higher degree of stringency was used given that multiple comparisons frequently lead a result to be significant at the $P<0.05$ level.

\section{References}

1 Smeja C, Brassard P. Tuberculosis infection in an Aboriginal (First Nations) population of Canada. Int I Tuberc Lung Dis 2000; 4: 925

2 FitzGerald M, Wang L, Elwood RK. Tuberculosis: 13. Control of the disease among Aboriginal people in Canada. Can Med Assoc J 2000; 162: 351.

3 Canada H. Tuberculosis in First Nations Communities, 1999. Minister of Public Works and Government Services Canada: Ottawa, 1999.

4 Meissner HC. Selected populations at increased risk from respiratory syncytial virus infection. Pediatr Infect Dis J 2003; 22 (Suppl): 40.

5 Banerji A, Bell A, Mills E et al. Lower respiratory tract infections in Inuit infants on Baffin Island. Can Med Assoc J 2001; 164: 1847

6 Welliver R. Respiratory syncytial virus and other respiratory viruses. Pediatr Infect Dis J 2003; 22 (Suppl): 6.

7 Grzybowski S, Allen E. Tuberculosis: 2. History of the disease in Canada. Can Med Assoc J 1999; 160: 1025.

8 Trimble M. Epidemiology on the Northern Plains: a Cultural Perspective. University of Missouri: Columbia, 1985.

9 Waldram J, Herring DA, Young TK. Aboriginal Health in Canada: Historical, Cultural, and Epidemiological Perspectives. University of Toronto Press: Toronto, 1995.

10 Scharton-Kersten TM, Wynn TA, Denkers EY et al. In the absence of endogenous IFN-gamma, mice develop unimpaired IL-12 responses to Toxoplasma gondii while failing to control acute infection. I Immunol 1996; 157: 4045.

11 Reiner SL, Locksley RM. The regulation of immunity to Leishmania major. Annu Rev Immunol 1995; 13: 151.

12 Nishikomori R, Gurunathan S, Nishikomori K, Strober W. $\mathrm{BALB} / \mathrm{c}$ mice bearing a transgenic IL-12 receptor beta 2 gene exhibit a nonhealing phenotype to Leishmania major infection despite intact IL-12 signaling. J Immunol 2001; 166: 6776.

13 Von Stebut E, Ehrchen JM, Belkaid Y et al. Interleukin 1alpha promotes Th1 differentiation and inhibits disease progression in Leishmania major-susceptible BALB/c mice. J Exp Med 2003; 198: 191.

14 Nagabhushanam V, Solache A, Ting LM, Escaron CJ, Zhang JY, Ernst JD. Innate inhibition of adaptive immunity: Mycobacterium tuberculosis-induced IL-6 inhibits macrophage responses to IFN-gamma. J Immunol 2003; 171: 4750.

15 Kwok P, Chen X. Detection of single nucleotide polymorphisms. Curr Issues Mol Biol 2003; 5: 43.

16 Louis E, Franchimont D, Piron A et al. Tumour necrosis factor (TNF) gene polymorphism influences TNF-alpha production in lipopolysaccharide (LPS)-stimulated whole blood cell culture in healthy humans. Clin Exp Immunol 1998; 113: 401.

17 Wilson AG, Symons JA, McDowell TL, McDevitt HO, Duff GW. Effects of a polymorphism in the human tumor necrosis factor alpha promoter on transcriptional activation. Proc Natl Acad Sci USA 1997; 94: 3195.

18 Kroeger KM, Carville KS, Abraham LJ. The -308 tumor necrosis factor-alpha promoter polymorphism effects transcription. Mol Immunol 1997; 34: 391.

19 Allen RD. Polymorphism of the human TNF-alpha promoter-random variation or functional diversity? Mol Immunol 1999; 36: 1017.

20 Turner DM, Williams DM, Sankaran D et al. An investigation of polymorphism in the interleukin-10 gene promoter. Eur J Immunogenet 1997; 24: 1-8.

21 Pravica V, Perrey C, Stevens A, Lee JH, Hutchinson IV. A single nucleotide polymorphism in the first intron of the human IFN-gamma gene: absolute correlation with a polymorphic CA microsatellite marker of high IFN-gamma production. Hum Immunol 2000; 61: 863.

22 Fishman D, Faulds G, Jeffery $R$ et al. The effect of novel polymorphisms in the interleukin-6 (IL-6) gene on IL-6 transcription and plasma IL-6 levels, and an association with 
systemic-onset juvenile chronic arthritis. J Clin Invest 1998; 102: 1369.

23 Terry CF, Loukaci V, Green FR. Cooperative influence of genetic polymorphisms on interleukin-6 transcriptional regulation. J Biol Chem 2000; 275: 18138.

24 Pravica V, Asderakis A, Perrey C, Hajeer A, Sinnott PJ, Hutchinson I. In vitro production of IFN-gamma correlates with CA repeat polymorphism in the human IFN-gamma gene. Eur J Immunogenet 1999; $26: 1$.

25 Pravica V, Perrey C, Stevens A, Lee JH, Hutchinson IV. A single nucleotide polymorphism in the first intron of the human IFN-gamma gene: absolute correlation with a polymorphic CA microsatellite marker of high IFN-gamma production. Hum Immunol 2000; 61: 863.

26 Cohen M. Health and the Rise of Civilization. Yale University Press: New Haven, Connecticut, 1989.

27 Lipsitch M, Sousa AO. Historical intensity of natural selection for resistance to tuberculosis. Genetics 2002; 161: 1599.

28 McNeill W. Plagues and Peoples. Anchor Books: New York, 1998.

29 Newport M, Huxley C, Huston S et al. A mutation in the interferon? Receptor gene and susceptibility to mycobacterial infection. N Engl J Med 1996; 335: 1941.

30 Lim W, Powell R, Johnston I. Tuberculosis and treatment with infliximab. N Engl J Med 2002; 346: 623.

31 Mira JP, Cariou A, Grall F et al. Association of TNF2, a TNFalpha promoter polymorphism, with septic shock susceptibility and mortality: a multicenter study. J Am Med Assoc 1999; 282: 561.

32 Hajeer A, Hutchinson I. TNF-a gene polymorphism: clinical and biological implications. Microsc Res Tech 2000; 50: 216.

33 Bayley JP, Ottenhoff TH, Verweij CL. Is there a future for TNF promoter polymorphisms? Genes Immun 2004; 5: 315.

34 Hoffmann SC, Stanley EM, Cox ED et al. Ethnicity greatly influences cytokine gene polymorphism distribution. Am J Transplant 2002; 2: 560.

35 Cuenca J, Perez CA, Aguirre AJ, Schiattino I, Aguillon JC. Genetic polymorphism at position -308 in the promoter region of the tumor necrosis factor (TNF): implications of its allelic distribution on susceptibility or resistance to diseases in the Chilean population. Biol Res 2001; 34: 237.

36 McGuire W, Knight JC, Hill AV, Allsopp CE, Greenwood BM, Kwiatkowski D. Severe malarial anemia and cerebral malaria are associated with different tumor necrosis factor promoter alleles. J Infect Dis 1999; 179: 287.

37 Flynn J, Chan J. Immunology of tuberculosis. Annu Rev Immunol 2000; 19: 93.

38 Jouanguy E, Altare F, Lamhamedi S et al. Interferon? Receptor deficiency in an infant with fatal bacille Calmette-Guerin infection. N Engl J Med 1996; 335: 1956.

39 Dobyns HF. Their Number Become Thinned. Native American Population Dynamics in Eastern North America. University of Tennessee Press: Knoxville, 1983.

40 Ramenofsky A. Vectors of Death: The Archaeology of European Contact. University of New Mexico Press: Albuquerque, 1987.
41 Verano J, Ubelaker D. Disease and Demography in the Americas. Smithsonian Institution Press: Washington, 1992.

42 Ubelaker D. North American Indian population size, A.D. 1500-1985. Am J Phys Anthropol 1988; 77: 289.

43 Schweger CE. The full-glacial ecosystem of Beringia. Prehist Mongoloid Dispersals 1990; 7: 35.

44 Turner C. The first Americans: the dental evidence. Natl Geogr Res 1986; 2: 37.

45 Merbs C. Patterns of activity-induced pathology in a Canadian Inuit population. National Museum of Man Mercury Series No. 119, 1983

46 Wright JV. A History of the Native People of Canada. Canadian Museum of Civilization: Hull, PQ, 1995.

47 McGhee R. Disease and the development of Inuit culture. Curr Anthropol 1994; 35: 565.

48 Merbs C. A new world of infectious disease. Yearbook Phys Anthropol 1992; 35: 3.

49 Buikstra J. The Caribou Eskimo: general and specific disease. Am J Phys Anthropol 1976; 45: 351.

50 Pfeiffer S. Paleopathology in an Iroquoian Ossuary, with Special Reference to Tuberculosis. Am J Phys Anthropol 1984; 65: 181.

51 Cybulski JS. Cribra orbitalia, a possible sign of anemia in early historic Native populations of the British Columbia coast. Am J Phys Anthropol 1977; 47: 31.

52 Powell ML. Health and disease in the late prehistoric Southeast. In: Verano JW, Ubelaker DH (eds). Disease and Demography in the Americas. Smithsonian Institution Press: Washington, 1992, p 41.

53 Marquet S, Abel L, Hillaire D, Dessein A. Full results of the genome-wide scan which localises a locus controlling the intensity of infection by Schistosoma mansoni on chromosome 5q31-q33. Eur J Hum Genet 1999; 7: 88.

54 Linker-Israeli M, Wallace DJ, Prehn J et al. Association of IL-6 gene alleles with systemic lupus erythematosus (SLE) and with elevated IL-6 expression. Genes Immun 1999; 1: 45.

55 Pascual M, Nieto A, Mataran L, Balsa A, Pascual-Salcedo D, Martin J. IL-6 promoter polymorphisms in rheumatoid arthritis. Genes Immun 2000; 1: 338

56 Omoto K. Genetic origins of the Philippine Negritos. Curr Anthropol 1981; 22: 421.

57 Bautista V. The Filipino Americans. Their History, Culture and Traditions. Bookhaus Publishers: Farmington Hills, 1998.

58 Elias B. The influence of the social environment on the health of Manitoba First Nations communities. Int J Circumpolar Health 2004; 63: 192.

59 Ferguson R. Tuberculosis Among the Indians of the Great Canadian Plains. Adlard and Sons Limited: London, 1928.

60 Hrdlicka A. Contribution to the Study of Tuberculosis in the Indian. Transactions of the Sixth International Congress on Tuberculosis: Washington, Philadelphia, 1908, p 480.

61 Hurtado AM, Hill KA, Rosenblatt W, Bender J, Sharmen T. Longitudinal study of tuberculosis outcomes among immunologically naive Aché Natives of Paraguay. Am J Phys Anthropol 2003; 121: 134. 